Article

\title{
Perception-Based Study on the Value of Nature to People and Land Sparing for Nature in Brazil and Poland
}

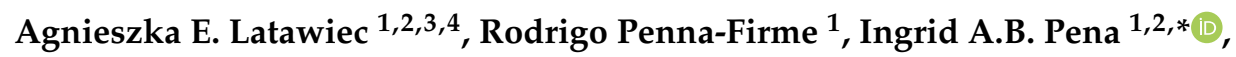
Bernardo B.N. Strassburg ${ }^{1,2,5,6}$, Adam Drosik ${ }^{7}$, Maciej Kubon ${ }^{3,8}{ }^{\circledR}$, Hubert Latala ${ }^{9}$,

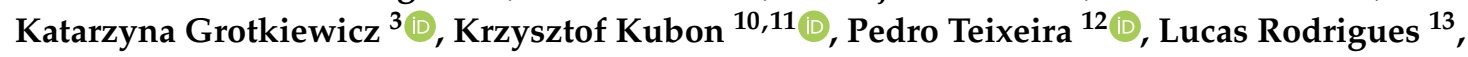
Alvaro Iribarrem ${ }^{2}$, Stanisław Famielec ${ }^{9}$, Dominika Springer ${ }^{7}$ and Isabella Leite Lucas ${ }^{2}$ (I)

1 Department of Geography and Environment, Pontifical Catholic University of Rio de Janeiro, Rio de Janeiro 22453900, Brazil; a.latawiec@iis-rio.org (A.E.L.); rodrigopennafirme@gmail.com (R.P.-F.); b.strassburg@iis-rio.org (B.B.S.)

2 International Institute for Sustainability, Rio de Janeiro 22460-320, Brazil; a.iribarrem@iis-rio.org (A.I.); i.leite@iis-rio.org (I.L.L.)

3 Department of Production Engineering, Logistics and Applied Computer Science, Faculty of Production and Power Engineering, University of Agriculture in Krakow, Kraków 30-149, Poland; maciej.kubon@urk.edu.pl (M.K.); katarzyna.grotkiewicz@urk.edu.pl (K.G.)

4 School of Environmental Sciences, University of East Anglia, Norwich NR4 7TJ, UK

5 Programa de Pós Graduacão em Ecologia, Universidade Federal do Rio de Janeiro, Rio de Janeiro 21941-590, Brazil

6 Botanical Garden Research Institute of Rio de Janeiro, R. Jardim Botânico 1008, Rio de Janeiro-RJ 22460-030, Brazil

7 Institute of Political Science and Administration, Opole University, Opole 45-040, Poland; adam_drosik@wp.pl (A.D.); d.springer@humandoc.pl (D.S.)

8 Eastern European State College of Higher Education in Przemyśl, Przemyśl 37-700, Poland

9 Faculty of Production and Power Engineering, University of Agriculture in Krakow, Kraków 30-149, Poland; rtlatala@cyf-kr.edu.pl (H.L.); stanislaw.famielec@urk.edu.pl (S.F.)

10 Association Project Tarnów, Rynek 9, 33-100 Tarnów, Poland; kkubon@hotmail.com

11 Institute of Political Science and International Relations, Jagiellonian University in Krakow, ul. Jabłonowskich 5, 31-114 Krakow, Poland

12 Department of Education, Pontifical Catholic University of Rio de Janeiro, 22453900, Rio de Janeiro, Brazil; pedro.teixeira@puc-rio.br

13 Department of Earth System Sciences, University of California Irvine, Irvine, CA 92697, USA; lr.modelagem@gmail.com

* Correspondence: i.pena@iis-rio.org

Received: 28 August 2020; Accepted: 4 October 2020; Published: 26 October 2020

check for updates Abstract: Understanding perception about nature is paramount to understanding human behavior
and decision making on the environment. We performed a survey-based study in Brazil and Poland
to better understand the perception of land sparing for nature and the perceived value of nature.
The countries were selected by intentional sampling and given their importance for local and global
biodiversity conservation, and complex socio-ecological context of conservation versus agroforestry
business. We performed an online questionnaire ( $\mathrm{N}=1030)$ in Brazil and face-to-face interviews
in Poland ( $\mathrm{N}=322)$. We found that Brazilian respondents demonstrated more pro-environmental
attitudes than Polish survey participants. Regarding the question: "How much nature that is left
should be spared?", nearly $51 \%$ of Brazilians answered "everything", compared with $13 \%$ of Polish
respondents. Just under half of the respondents from Poland ( $45.6 \%)$ indicated that half of the nature
that is left should be spared. Brazilian respondents also perceived the intrinsic value of nature to a
greater extent compared with Polish respondents; in total, $76 \%$ of Brazilians respondents entirely
agreed that "Nature, its plants and animals have a value on their own, independent of their usefulness 
for us" versus $25 \%$ of Polish respondents. Our study contributes to a better understanding of the leverage points driving pro-environmental attitudes in both countries.

Keywords: land sparing; the value of nature; perception-based study

\section{Introduction}

Understanding the perception of the environment is paramount for implementing on-the-ground initiatives, formulation of environmental policies, and promoting long-term behavior towards sustainability. The importance of understanding the relationship between perception and attitudes is well analyzed in the scientific literature [1]. Environmental problems are often linked to the result of human behavioral choices; hence resolving these problems can, at least partially, be facilitated by understanding and influencing human behavior [2]. There are several questions about what leads to environmental awareness and the willingness to live according to more sustainable choices. The perception is linked to the values of individuals, which are the basis for more specific attitudes and behaviors [3]. Values are a reflection of the experiences lived by each individual, which are influenced by an historical and cultural context [4].

In this study, we investigate the perception of the value of nature in Brazil and Poland. By "nature" we mean "areas containing elements of living systems that include plants and nonhuman animals across a range of scales and degrees of human management, from a small urban park through to relatively "pristine wilderness" [5]. From a social standpoint, Brazilian society has already shown its pro-environmental attitudes [6-10]. In the 2014 Zoological Society of London Global Survey, Brazilian respondents expressed that $60 \%$ of Brazilian territory should be protected, representing the highest proportion of respondents of all the countries surveyed [11]. Brazil's immense natural capital, also expressed in its cultural diversity, provides the conditions for the transformation of conservation and sustainable use of environmental assets into sustainable development opportunities such as protection of pristine areas along with a reduction in poverty and socioeconomic inequity [12-15]. Brazil is the largest country in South America and Latin America, and the fifth-largest country in the world in terms of population and size. Brazil is a developing country with a life expectancy increasing over recent years. Aside from favorable aspects related to country's development, projected increase in life expectancy means higher demand for environmental resources. According to data from the National Household Sample Survey [16] of 2015, 85\% of the Brazilian population lives in urban areas. Regarding the level of education, in 2018, $48 \%$ of the Brazilian population over 25 years old was concentrated in levels of education up to complete elementary school; $27 \%$ had completed high school; and $16.5 \%$, higher level.

Polish citizens increasingly recognize environmental protection as an important area of state activity. In 2018, 18\% of respondents considered that environmental protection belongs to the three areas of the country's most challenging activity, compared to 7\% in 2012 [17]. Public attention in Poland is attracted by such problems as (1) changes in energy production towards climate protection, which is particularly important in the case of Poland with its highly coal-dependent energy sector [18]; (2) heavy air pollution (smog) in residential areas and the resulting health problems of citizens $[19,20]$, as well as (3) the issue of protecting valuable natural ecosystems, particularly noticeable in the case of discussions on logging in one of the last remaining primeval forests in lowland Europe, Białowieża Forest [21,22], a refuge for European bison (Bison bonasus), the largest land mammal on the continent [23].

We performed a survey to examine the perceived importance of nature conservation among people in Brazil and Poland. This study has three main objectives: to survey the opinion between Polish and Brazilian residents about (1) the importance of sparing land for nature, (2) identifying principal problems related to the environment, (3) investigating the perception of the value of nature. 
Although the question of whether nature should be spared has been investigated previously (e.g., [11]), to our knowledge, this is the first study that asks the public how much of that nature should be spared. Our study was not designed to be representative. Rather, it presents two case studies that we compare. Both approaches were performed according to scientific standards of each method. In both cases, sampling was opportunistic and adjusted to financial and practical limitations of the study. In addition, even though our respondents may not directly be responsible for environmental degradation that may indeed take place indirectly, for instance, via telecoupled consumption. The results of this study could help implement nature conservation and development policies by emphasizing the importance of society's voice in determining appropriate environmental protection priorities and measures.

\section{Materials and Methods}

\subsection{Survey}

The study was carried out over 2017 and 2018. In Poland, we conducted 322 face-to-face interviews of students and random respondents in four voivodeships (a highest-level administrative subdivision of Poland): (1) Krakow (the second-biggest city in Poland), Malopolska voivodeship (south/south-east of Poland), (2) Olsztyn (capital of voivodeship), Warminsko-Mazurskie voivodeship (northeast of Poland), (3) Opole (capital of voivodeship), Opolskie voivodeship (south-west of Poland), and (4) Tarnow, a city in Malopolskie voivodeship (south-east of Poland). A table with the percentage of respondents in relation to the cities is found in the Supplementary Materials (Table S1). In Brazil, an online questionnaire was disseminated via social media (Facebook, Instagram) and snowball sampling $(\mathrm{N}=1030)$.

The survey included the following questions:

1. How much nature that is left should be spared? Answer options (single response): Everything $(100 \%)$; Majority (75\%); Half (50\%); One-quarter (25\%); One-tenth (10\%); Nothing (0\%) or I don't know.

2. What is the urgency to solve the following environmental problems: air pollution, sea pollution, river pollution, deforestation, climate change, water scarcity, lack of sanitation, species extinction, the use of pesticides, soil erosion? Answer options (single response for each environmental problem): Low; medium; high.

3. Please indicate to what extent you agree with the following statements: (a) Nature, its plants and animals have a value on their own, independent of their usefulness for us. (b) Nature has value only because it brings benefits to humankind. Answer options (single response for each sub-question): Completely agree; Partially agree; Partially disagree; Completely disagree; I don't know.

4. Background questions: age, gender, level of education, and place of residence (for Poland: city >100,000 inhabitants; city <100,000 inhabitants; village/ For Brazil: Rural; Urban)

The results were analyzed in both Polish and Portuguese. The responses were then translated into English. The versions of the questions in Polish and in Portuguese can be found in the Supplementary Materials (Method S1). The interview responses were transcribed into Excel and subsequently transferred to Statistical Package for the Social Sciences (SPSS) and R.

\subsection{Statistical Analyses}

We used descriptive statistics (performed in SPSS) for all the tables shown in this paper and Tables S3 and S4 (found in Supplementary Materials), which mainly present the frequencies for each answer. We used R software [24] to calculate the correlations between age and gender data and responses regarding the urgency to solve environmental problems for Table S2. 


\section{Results}

\subsection{Respondents' Background}

Table 1 presents the respondents' background. Most of the Polish respondents were university students, with complete secondary education (84\%), and residents of cities $>100,000$ inhabitants $(63.2 \%)$, men (56.7\%), and young, i.e., under 30 (73.2\%). The Brazilian respondents were mostly women (51\%), young $(45.4 \%)$, residents of urban areas $(77.7 \%)$, and higher educated $(41.6 \%)$.

Table 1. Respondents' background.

\begin{tabular}{cccc}
\hline Age (Years) & Poland & Brazil \\
\hline$<30$ & \multicolumn{1}{c}{$\%$} \\
$30-55$ & 73.2 & 45.4 \\
$>55$ & 2.2 & 29.0 \\
Did not answer & 24.6 & 6.8 \\
Gender & & & 18.7 \\
Male & & $\%$ & \\
Female & 56.7 & & 32.0 \\
Place of living & 43.3 & & 51.1 \\
City $>$ 100,000 habitants & & $\%$ & \\
City $<$ 100,000 habitants & 63.2 & & N/A \\
Village & 17.8 & & N/A \\
Rural & 19 & & N/A \\
Urban & N/A & & 2.3 \\
Missing & N/A & & 77.7 \\
Level of education & N/A & 20 \\
Primary & & $\%$ & \\
Secondary & 0.9 & 3.0 \\
Technical & 84.1 & 37.1 \\
Higher & 10.3 & 1.1 \\
None or did not answer & 4.7 & 41.6 \\
& 0 & 17.3 \\
\hline
\end{tabular}

\subsection{How Much Nature That Is Left Should Be Spared?}

We found a difference between Brazilian and Polish respondents with respect to the question of how much nature that is left should be spared (Table 2). Nearly $13 \%$ of Polish respondents indicated "everything" compared with 51\% of Brazilians. Just under half of the respondents from Poland (45.5\%) indicated that half of the nature that is left now should be spared, compared with only $2.5 \%$ of Brazilian respondents. The percentages of respondents in both countries that believed that $50 \%$ of nature or more should be spared were similar: in Brazil 85.1\% and in Poland, 85.2\%.

Table 2. How much nature that is left should be spared? Responses from Brazil and Poland.

\begin{tabular}{ccccc}
\hline & \multicolumn{2}{c}{ Poland } & \multicolumn{2}{c}{ Brazil } \\
\hline Percentage of nature that is left that should be spared & $\mathbf{N}$ & $\mathbf{\%}$ & $\mathbf{N}$ & $\%$ \\
Everything $(100 \%)$ & 41 & 12.80 & 525 & 51.0 \\
Majority (75\%) & 95 & 29.40 & 326 & 31.7 \\
Half (50\%) & 146 & 45.60 & 26 & 2.5 \\
One-quarter (25\%) & 28 & 8.80 & 10 & 1.0 \\
One-tenth (10\%) & 6 & 1.90 & 2 & 0.2 \\
Nothing or I don't know or missing & 5 & 1.50 & 141 & 13.7 \\
Total & 321 & 100.00 & 1030 & 100 \\
\hline
\end{tabular}

Regarding age association (Table 3), we found that most of the older Polish respondents claimed that half of what is left should be spared, while most of the respondents of age under 55 declared it 
should be the majority of it. In Brazil, in all age groups, we found that most respondents believed that $100 \%$ of nature should be spared (Table 4). For Brazil, the answer had a significantly higher correlation coefficient with age (correlation $=-0.19, p<0.01, \mathrm{~N}=183$ ). The relation was monotonically inverse, indicating that older people tend to claim that less nature should be preserved.

Table 3. How much nature that is left should be spared-age association. Responses for Poland.

\begin{tabular}{|c|c|c|c|c|c|c|c|c|}
\hline \multirow{2}{*}{\multicolumn{2}{|c|}{ Age of Respondent }} & \multicolumn{6}{|c|}{ How Much Nature Should Be Spared (Poland)? } & \multirow[b]{2}{*}{ Total } \\
\hline & & $\begin{array}{c}\text { Everything } \\
(100 \%)\end{array}$ & $\begin{array}{c}\text { Majority } \\
(75 \%)\end{array}$ & $\begin{array}{l}\text { Half } \\
(50 \%)\end{array}$ & $\begin{array}{l}\text { One-Quarter } \\
(25 \%)\end{array}$ & $\begin{array}{c}\text { One-Tenth } \\
(10 \%)\end{array}$ & $\begin{array}{l}\text { I Don't Know } \\
\text { or Nothing }\end{array}$ & \\
\hline \multirow{2}{*}{$<30$} & $n$ & 39 & 88 & 86 & 11 & 6 & 4 & 234 \\
\hline & $\%$ & $16.70 \%$ & $37.60 \%$ & $36.80 \%$ & $4.70 \%$ & $2.60 \%$ & $1.70 \%$ & $100 \%$ \\
\hline \multirow{2}{*}{$30-55$} & $n$ & 1 & 4 & 1 & 0 & 0 & 1 & 7 \\
\hline & $\%$ & $14.30 \%$ & $57.10 \%$ & $14.30 \%$ & $0.00 \%$ & $0.00 \%$ & $14.30 \%$ & $100 \%$ \\
\hline \multirow{2}{*}{$>55$} & $n$ & 1 & 2 & 59 & 17 & 0 & 0 & 79 \\
\hline & $\%$ & $1.30 \%$ & $2.50 \%$ & $74.70 \%$ & $21.50 \%$ & $0.00 \%$ & $0.00 \%$ & $100 \%$ \\
\hline \multirow{2}{*}{ Total } & $n$ & 41 & 94 & 146 & 28 & 6 & 5 & 320 \\
\hline & $\%$ & $12.80 \%$ & $29.40 \%$ & $45.60 \%$ & $8.80 \%$ & $1.90 \%$ & $1.50 \%$ & $100 \%$ \\
\hline
\end{tabular}

Table 4. How much nature that is left should be spared-age association. Responses for Brazil.

\begin{tabular}{|c|c|c|c|c|c|c|c|c|c|}
\hline \multirow{2}{*}{\multicolumn{2}{|c|}{ Age of Respondent }} & \multicolumn{7}{|c|}{ How Much Nature That Is Left Should Be Spared (Brazil)? } & \multirow[b]{2}{*}{ Total } \\
\hline & & $\begin{array}{c}\text { Everything } \\
(100 \%)\end{array}$ & $\begin{array}{c}\text { Majority } \\
(75 \%)\end{array}$ & $\begin{array}{c}\text { Half } \\
(50 \%)\end{array}$ & $\begin{array}{c}\text { One-Quarter } \\
(25 \%)\end{array}$ & $\begin{array}{c}\text { One-Tenth } \\
(10 \%)\end{array}$ & $\begin{array}{c}\text { I Don't Know } \\
(0 \%)\end{array}$ & Missing & \\
\hline \multirow{2}{*}{$<30$} & $n$ & 265 & 181 & 14 & 6 & 0 & 0 & 2 & 468 \\
\hline & $\%$ & $56.62 \%$ & $38.68 \%$ & $2.99 \%$ & $1.28 \%$ & $0.00 \%$ & $0.00 \%$ & $0.43 \%$ & $100 \%$ \\
\hline \multirow{2}{*}{$30-55$} & $n$ & 193 & 93 & 8 & 2 & 1 & 0 & 2 & 299 \\
\hline & $\%$ & $64.55 \%$ & $31.10 \%$ & $2.68 \%$ & $0.67 \%$ & $0.33 \%$ & $0.00 \%$ & $0.67 \%$ & $100 \%$ \\
\hline \multirow{2}{*}{$>55$} & $n$ & 34 & 33 & 1 & 0 & 1 & 0 & 1 & 70 \\
\hline & $\%$ & $48.57 \%$ & $47.14 \%$ & $1.43 \%$ & $0.00 \%$ & $1.43 \%$ & $0.00 \%$ & $1.43 \%$ & $100 \%$ \\
\hline \multirow{2}{*}{ Missing } & $n$ & 33 & 19 & 3 & 2 & 0 & 0 & 136 & 193 \\
\hline & $\%$ & $17.10 \%$ & $9.84 \%$ & $1.55 \%$ & $1.04 \%$ & $0.00 \%$ & $0.00 \%$ & $70.47 \%$ & $100,0 \%$ \\
\hline \multirow{2}{*}{ Total } & $n$ & 525 & 326 & 26 & 10 & 2 & 0 & 141 & 1030 \\
\hline & $\%$ & $50.97 \%$ & $31.65 \%$ & $2.52 \%$ & $0.97 \%$ & $0.19 \%$ & $0.00 \%$ & $13.69 \%$ & $100 \%$ \\
\hline
\end{tabular}

\subsection{The Urgency to Solve Environmental Problems}

Concerning the urgency to solve environmental problems (Table 5), the respondents from Poland indicated as the most urgent problems "water scarcity", "air pollution", and "river pollution". According to Brazilian respondents, the most urgent problems were "river pollution", "deforestation", and "lack of sanitation". For both Polish and Brazilian respondents, the least urgent environmental problem was "soil erosion".

In the correlation of responses with age and gender data (Table S2), we found that in Brazil, as age increased, the higher the tendency for Brazilian men to think that soil erosion (34\%) had high urgency. There was also an influence on the increase in age for pesticides $(28 \%)$, deforestation (28\%), and lack of sanitation (24\%). Regarding Brazilian women, there was a correlation between increasing age when considering pesticides (19\%) as having high urgency. In relation to Polish men, a correlation was found between younger respondents who found air pollution (69\%), river pollution (56\%), species extinction $(53 \%)$, sea pollution $(49 \%)$, and soil erosion $(45 \%)$ as having high urgency. Regarding Polish women, the younger the respondent, the higher the chance for them to find soil erosion $(68 \%)$, sea pollution $(58 \%)$, river pollution $(58 \%)$, air pollution $(38 \%)$, and deforestation $(37 \%)$ as having high urgency. 
Table 5. Level of urgency to solve environmental problems.

\begin{tabular}{cccc}
\hline Environmental Problem & Low & $\begin{array}{c}\text { Urgency } \%(n) \\
\text { Medium }\end{array}$ & High \\
POLAND & & & \\
\hline Air pollution & $9.3(30)$ & $38.8(125)$ & $51.9(167)$ \\
Sea pollution & $20.8(67)$ & $48.8(156)$ & $30.7(99)$ \\
River pollution & $16.1(52)$ & $32.6(105)$ & $51.2(185)$ \\
Deforestation & $24.5(79)$ & $49.1(158)$ & $26.4(85)$ \\
Climate change & $25.0(80)$ & $42.2(135)$ & $32.8(105)$ \\
Water scarcity & $10.2(33)$ & $35.4(114)$ & $54.3(175)$ \\
Lack of sanitation & $9.3(30)$ & $49.1(158)$ & $41.6(134)$ \\
Species extinction & $25.2(81)$ & $36.4(117)$ & $38.3(123)$ \\
The use of pesticides & $25.8(83)$ & $43.3(139)$ & $30.8(99)$ \\
Soil erosion & $33.9(109)$ & $56.2(181)$ & $9.9(32)$ \\
BRAZIL & Low & Medium & High \\
Air pollution & $1.76 \%(18)$ & $21.46 \%(220)$ & $76.78 \%(787)$ \\
Sea pollution & $0.78 \%(8)$ & $12.29 \%(126)$ & $86.93 \%(891)$ \\
River pollution & $0.5 \% \%(6)$ & $5.37 \%(55)$ & $94.05 \%(964)$ \\
Deforestation & $0.68 \%(7)$ & $9.16 \%(94)$ & $90.16 \%(925)$ \\
Climate change & $7.02 \%(72)$ & $25.34 \%(260)$ & $67.64 \%(694)$ \\
Water scarcity & $1.85 \%(19)$ & $14.72 \%(151)$ & $83.43 \%(856)$ \\
Lack of sanitation & $1.36 \%(14)$ & $11.01 \%(113)$ & $87.62 \%(899)$ \\
Species extinction & $3.61 \%(37)$ & $21.95 \%(225)$ & $74.44 \%(763)$ \\
The use of pesticides & $4.78 \%(49)$ & $19.71 \%(202)$ & $75.51 \%(774)$ \\
Soil erosion & $5.37 \%(55)$ & $33.85 \%(347)$ & $60.78 \%(623)$ \\
\hline
\end{tabular}

\subsection{The Value of Nature to People}

We found a difference in the perception of the value of nature between the respondents from both countries (Table 6). In Brazil, respondents perceived the intrinsic value of nature to a greater extent than those in Poland. In Poland, younger respondents were more likely than older ones to consider that nature has value in itself. In terms of gender, our results showed that more women than men perceived the intrinsic value of nature. We also observed that in Poland, residents of smaller cities or villages perceived the value of nature to a greater extent than residents of larger cities.

Table 6. Percentage of agreement with the sentences on the value of nature.

\begin{tabular}{|c|c|c|c|c|c|c|}
\hline Poland & $\begin{array}{l}\text { Completely } \\
\text { Agree }\end{array}$ & $\begin{array}{l}\text { Partially } \\
\text { Agree }\end{array}$ & $\begin{array}{l}\text { Partially } \\
\text { Disagree }\end{array}$ & $\begin{array}{l}\text { Completely } \\
\text { Disagree }\end{array}$ & $\begin{array}{l}\text { I Don't } \\
\text { Know }\end{array}$ & \\
\hline $\begin{array}{l}\text { Nature, its plants and animals have a value on } \\
\text { their own, independent of their usefulness for us. }\end{array}$ & $24.9 \%(80)$ & $39.6 \%$ (127) & $30.2 \%(97)$ & $4.4 \%(14)$ & $0.9 \%(3)$ & \\
\hline $\begin{array}{l}\text { Nature has a value only because it brings benefits } \\
\text { to humankind. }\end{array}$ & $5 \%(16)$ & $22.1 \%(71)$ & $42.4 \%(136)$ & $28.3 \%(91)$ & $2.2 \%(7)$ & \\
\hline Brazil & $\begin{array}{l}\text { Completely } \\
\text { agree }\end{array}$ & $\begin{array}{l}\text { Partially } \\
\text { agree }\end{array}$ & $\begin{array}{l}\text { Partially } \\
\text { disagree }\end{array}$ & $\begin{array}{l}\text { Completely } \\
\text { disagree }\end{array}$ & $\begin{array}{l}\text { I don't } \\
\text { know }\end{array}$ & Missing \\
\hline $\begin{array}{l}\text { Nature, its plants and animals have a value on } \\
\text { their own, independent of their usefulness for us. }\end{array}$ & $75.9 \%(782)$ & $7.6 \%(78)$ & $1.1 \%(11)$ & $1.4 \%(14)$ & $0.6 \%(6)$ & $13.5 \%$ (139) \\
\hline $\begin{array}{l}\text { Nature has a value only because it brings benefits } \\
\text { to humankind. }\end{array}$ & $6.7 \%(69)$ & $6.0 \%(62)$ & $12.1 \%(125)$ & $60.5 \%(623)$ & $1.4 \%(14)$ & $13.3 \%(137)$ \\
\hline
\end{tabular}

In Brazil, women were more likely to express that "Nature, its plants and animals have value in themselves, regardless of whether they are useful to us" ( $\mathrm{rs}=0.088, p<0.01)$ and to disagree that "Nature has value only because it benefits humanity" ( $\mathrm{rs}=-0.138, p<0.01)$. The more educated the respondent, the less likely he or she was to agree that "Nature has value only because it benefits humanity" ( $r s=-0.122, p<0.01)$. There were also correlations between the way respondents perceived nature's value. There was a positive correlation between agreeing that "Nature brings benefits to humanity" and "Nature, its plants and animals have value in themselves, regardless of whether they are useful to us" ( $r s=0.190, p<0.01$ ). Finally, there was a negative correlation between agreeing that 
"Nature, its plants and animals have value in themselves, regardless of whether they are useful to us" and "Nature has value only because it benefits humanity" ( $\mathrm{rs}=-0.214, p<0.01)$.

In Poland, there was a small tendency for women to agree more than men with the intrinsic value of nature (Table S3). In relation to the agreement with the utilitarian value of nature, we found that, in Poland, there was a greater tendency among men of secondary and technical level, and among women of primary and higher education level (Table S4).

\section{Discussion}

The importance of the public perception of nature for decision making cannot be underestimated. It drives behavior, individual choices, trade, and political agendas. To our knowledge, our study is the first to seek the opinion of the opportunistically selected public about how much of the remaining nature should be spared, environmental problems, and the value of ecosystem services. We found a strong and consistent tendency towards a pro-environmental attitude among Brazilian respondents compared with people from other countries, in this instance, Poland. Our results confirmed those of Kümpel [11], who revealed Brazil as one of the most pro-environmental countries of seven countries surveyed (Australia, UK, Brazil, USA, China, India, and South Africa), at least in terms of the perceived importance of nature. The results showed that Brazilian respondents considered that $60 \%$ of Brazilian territory should be protected [11].

Holmes et al. (2017) [25] used questionnaires to empirically examine opinions on the "new conservation" held by attendees at the 2015 International Congress for Conservation Biology. Results showed differences between the debate on the new conservation in the literature and views held within a wider, but still limited, conservation community and demonstrated the existence of at least one viewpoint (in favor of conservation to benefit people but opposed to links with capitalism and corporations). This study originated "The Future of Conservation" (FoC) survey, which comprised an online questionnaire that placed the participant's position on two axes: whether their opinions were people- or nature-centered and whether they were pro- or anti-market, i.e., their scepticism about the role of markets, corporations, and capitalism for conservation. Using the FoC, [26] survey they characterized the views of 9264 conservationists from 149 countries, identifying specific areas of consensus and disagreement, and three independent dimensions of conservation thinking. The first two dimensions (people-centered conservation and science-led ecocentrism) have widespread support, whereas conservation through capitalism is more contentious. The authors highlighted relationships between dimension scores and respondents' gender, age, educational background, career stage, and the continent of nationality. The gender result of the FoC survey could be linked to the higher average levels of empathy for the well-being of other humans among women than men. Similarly, our results show that both in Brazil and in Poland, women were more likely to recognize the intrinsic value of nature.

The Brazilian respondents perceived river pollution as the most urgent environmental issue to be solved (94\%), representing problems that affect people's lives explicitly, including in urban areas where most respondents are. Some recent events may help to explain this result. In 2014 and 2015, much attention was given to the biggest water crisis in the state of São Paulo, the most populous state in the country. The crisis was related to poor management of the supply system in an atypical rain regime in the summer of 2014, well below historical averages, and the high temperatures that led to increased consumption [27]. Some studies endorse the hypothesis that deforestation in the Amazon is also one of the factors behind the lack of water in São Paulo [28,29]. In addition, two recent accidents in mines (2015 and 2019) are considered the worst environmental disasters that occurred in Brazil [30]. The first one resulted in the death of 19 people and rendered more than 300 families homeless. Thousands of tons of iron ore tailings were carried into the Doce River basin, reaching the Atlantic coast near the mouth of the river. The second one, at an iron ore mine, caused the disappearance of about 300 people. The northern region of the country, the birthplace of the Amazon, is the worst region in the country in terms of sewage collection and treatment. Thus, cities that bathe in Amazonian rivers dump sewage 
directly into rivers. A study carried out in 2019 shows that only $6.5 \%$ of Brazilian rivers have good water quality and that a large part of the country's watercourses is slowly losing the capacity to supply the population and even to harbor aquatic beings [31].

The second most urgent issue to be solved is deforestation (90\%). Deforestation of the Brazilian Amazon is not only recognized as a national challenge but also internationally. Deforestation has always been a complex problem in Brazil due to its direct association with agriculture [32], one of the core economic activities. Lack of sanitation was the third-highest priority issue identified by Brazilian respondents. Only $53.2 \%$ of the Brazilian population have sewage collection, $46.3 \%$ have treated sewage, and $83.6 \%$ have access to treated water [33]. The northern region, where the largest indigenous population in the country is located, is the one that least offers basic sanitation to the population. Until 2009, only $63.07 \%$ of the indigenous population in Brazil had access to treated water [34]. The situation is also alarming in slums and irregular areas in large cities across the country, where the poorest urban populations live. In the first three months of this year alone, the lack of sanitation has generated more than 40,000 hospitalizations in Brazil [35]. Even though this problem is identified by the population, it historically has not attracted the attention of decision-makers to be treated as a priority due to its "invisibility", resulting in low investment in the sector.

In Poland, water scarcity was pointed out by $54 \%$ of respondents as the most urgent issue to be solved. Poland is referred to as the "European Sahara" as it is one of the countries in Europe with the least available water per capita [36]. The capacity of storage reservoirs in Poland is minimal, and water shortages are predicted to occur with more frequency in the future. Besides, $52 \%$ of Polish respondents identified air pollution as an urgent issue, likely related to repeated events of smog in the country [37]. The issue of air pollution was also ranked highest (62\%) in the survey on ecological awareness in Poland, in which the respondents were asked to indicate the three most urgent environmental problems [17].

In Poland, soil erosion is the least perceived problem. This result confirms that the importance of soils is generally overlooked and underestimated [38], and its role in human life and in the conservation of biodiversity is not properly recognized [39]. Issues around soil conservation have been neglected [40], and the consequence is continued degradation through erosion, pollution, landslides, and silting up watercourses. Given the land scarcity and possible future food shortages, soil conservation calls for action [41,42]. This result confirms that there must be greater awareness of its importance. However, interestingly, in the correlation of responses with age and gender, we found that among younger Polish women and men there was a higher likelihood of finding soil erosion a high urgency issue.

The intrinsic value of nature was perceived to a higher extent by Brazilian than by Polish respondents, with $76 \%$ of Brazilian respondents entirely agreeing with the statement "Nature, its plants and animals have a value on their own, independent of their usefulness for us". In case of Poland, the survey results show that Polish respondents recognize to a lesser extent than Brazilian respondents the intrinsic value of nature-24.9\% entirely and $39.6 \%$ partially agreed that "Nature, its plants and animals have value in themselves, regardless of whether they are useful to us". For comparison, in the survey for the Polish Ministry of Environment, 35\% of respondents in Poland indicated that nature has value on its own and it is one of two main reasons for nature protection, more important being health protection (64\%) and the concern over the next generations (51\%) [17]. Values are related to environmentalism [3], but the sociocultural variation of values has not been explored enough in the literature [3]. Our study therefore complements the existing body of knowledge on perception of the value of nature in different countries and different contexts. Following other researchers [3], we highlight the importance of these types of studies for decision making as more research is needed to understand how value perception influences behavior and to improve methods for implementing values in collective decision making.

\section{Conclusions}

Studies on environmental perception are crucial for efficient decision making. To our knowledge, this is the first study to have examined public opinion about how much of the nature that remains 
should be spared. Our case study reveals interesting differences in the responses of the public from two economically and socioculturally dissimilar countries. We found that Brazilian respondents demonstrated more concerns related to the environment than Polish survey participants. This may be related to different relationships with nature and recent broad and impactful environmental problems in the country. The analysis of the perception of urgency about environmental problems also indicated relationships with recent disasters and circumstances in both countries, which provides an additional message to decision-makers regarding the impact of these events and priority to solve them. Perception drives behavior, and behavior influences decision making not only at household level but also policy-making choices, and understanding society views is paramount for directing the future path towards sustainability. The results of this study are therefore important for the emerging discussion on how much nature societies are willing to protect and what might be future focal points for action and environmental education. We also believe that the results of this study, by complementing the existing body of knowledge, could help guiding nature conservation and development policies.

Supplementary Materials: The following are available online at http://www.mdpi.com/2071-1050/12/21/8860/s1, Table S1: Percentage of respondents in relation to Polish cities, Method S1: Questions of the survey in Portuguese and in Polish, Table S2: Correlations between age and gender data and responses regarding the urgency to solve environmental problems Regarding age and urgency (R software), Table S3: Cross-tabulation - Level of agreement with the statement 'Nature, its plants and animals have a value on their own, independent of their usefulness for us' with gender and education level, Table S4: Cross-tabulation - Level of agreement with the statement 'Nature has a value only because it brings benefits to humankind' with gender and education level.

Author Contributions: Conceptualization, A.E.L., R.P.-F. and B.B.N.S.; methodology, A.E.L. and R.P.-F.; validation, A.E.L., L.R. and A.D.; formal analysis, A.E.L., P.T., L.R., A.D., M.K., K.K., I.L.L.; investigation, M.K., K.K., H.L., R.P.-F., K.G.; data curation, A.E.L, A.D., P.T., I.A.B.P.; —original draft preparation, A.E.L.; writing-review and editing, A.E.L., R.P.F, I.A.B.P., B.B.N.S., A.D., M.K., H.L., K.G., K.K., P.T., A.I., S.F., D.S., I.L.L.; visualization, I.A.B.P., P.T., L.R., A.D.; supervision, A.E.L., R.P.-F.; project administration, A.E.L., R.P.-F.; funding acquisition, A.E.L, R.P.-F., M.K. All authors have read and agreed to the published version of the manuscript.

Funding: This study was financed by Coordenação de Aperfeiçoamento de Pessoal de Nível (CAPES)—Finance Code 001; The Royal Society Newton Fund, project ID: NAF \R2\180676., Carlos Chagas Foundation for Research Support of the State of Rio de Janeiro (FAPERJ), project ID: E-26/202.680/2018, National Council for Scientific and Technological Development-CNPq, project ID: 308536/2018-5, project title: Sustaining the land from the ground up: developing soil carbon and soil ecosystem services valuation frameworks for tropical soils.

Acknowledgments: We thank Maiara S. Mendes for helping us with the manuscript editing. We thank the reviewers for their time and valuable comments.

Conflicts of Interest: The authors declare that they have no conflict of interest related to the publication of this manuscript.

\section{References}

1. Saunders, C.D. The emerging field of conservation psychology. Hum. Ecol. Rev. 2003, 10, 137-149. Available online: http://ajph.humanecologyreview.org/pastissues/her102/102saunders.pdf (accessed on 15 March 2020).

2. Clayton, S.; Myers, G. Conservation Psicology: Understanding and Promoting Human Care for Nature, 1st ed.; Wiley-Blackwell: Chichester, UK, 2009; p. 264.

3. Dietz, T.; Fitzgerald, A.; Shwon, R. Environmental values. Annu. Rev. Environ. Resour. 2005, 30, $335-372$. Available online: http://www.atmosp.physics.utoronto.ca/people/lev/ESSgc2/18920673.pdf (accessed on 15 March 2020). [CrossRef]

4. Garrido, L.S.; Meirelles, R.M.S. Percepção sobre meio ambiente por alunos das séries iniciais do Ensino Fundamental: Considerações à luz de Marx e de Paulo Freire. Ciência Educação 2014, 20, 671-685. [CrossRef]

5. Bratman, G.N.; Hamilton, J.P.; Daily, G.C. The impacts of nature experience on human cognitive function and mental health. Ann. N. Y. Acad. Sci. 2012, 1249, 118-136. [CrossRef] [PubMed]

6. Crespo, S.; Leitão, P. O Que o Brasileiro Pensa da Ecologia; Editora Brasil America: Rio de Janeiro, Brazil, 1993.

7. Dunlap, E.R.; Gallup, G.H.; Gallup, A.M. The Health of the Planet Survey, a Preliminary Report on At-Titudes Toward the Environment and Economic Growth Measured by Surveys of Citizens in 24 Nations to Date; The George H. Gallup International Institute: Princeton, NJ, USA, 1993. 
8. Dunlap, E.R.; Gallup, G.H.; Gallup, A. Global Environmental Concern-Results from an International Public Opinion Survey. Environment 1995, 35, 7-15.

9. Simões, S.; Hogan, D. Beyond the Rain Forest: Environmental attitudes and behavior among Brazilians. In Culture and Sustainability: A Cross-National Study of Cultural Diversity and Environmental Priorities among Mass Publics and Decision Makers; Ester, P., Vinken, H., Aoyagi-Usui, M., Eds.; Amsterdam University Press: Amsterdam, The Netherlands, 2003.

10. Research Memorandums. Brazilians Pessimistic About Environment and Brazilians Choose Environmental Protection Over Economic Growth; United States Information Agency: Washington, DC, USA, 1992.

11. Kümpel, N. Global Public Opinion Survey on Space for Nature. Zoological Society of London (ZSL) Presentation at the IUCN World Parks Congress 2014. At: Sydney, Australia Volume: Stream 1 Session on 'Beyond Aichi: Space for Nature'. Available online: https://www.researchgate.net/publication/295908866_ Global_public_opinion_survey_on_space_for_nature (accessed on 5 January 2020).

12. Joly, C.A.; Scarano, F.R.; Bustamante, M.; Gadda, T.M.C.; Metzer, J.P.W.; Seixas, C.S.; Ometto, J.P.H.B.; Pires, A.P.F.; Boesing, A.L.; Sousa, F.D.R.; et al. Brazilian assessment on biodiversity and ecosystem services: Summary for policy makers. Biota Neotropica 2019, 19. [CrossRef]

13. Latawiec, A.E.; Strassburg, B.B.N.; Valentim, J.F.; Ramos, F.; Alves-Pinto, H.N. Intensification of cattle ranching production systems: Socioeconomic and environmental synergies and risks in Brazil. Animal 2014, 8, 1255-1263. [CrossRef]

14. Latawiec, A.E.; Strassburg, B.B.N.; Brancalion, P.H.S.; Rodrigues, R.R.; Gardner, T. Creating space for large-scale restoration in tropical agricultural landscapes. Front. Ecol. Environ. 2015, 13, 211-218. [CrossRef]

15. Strassburg, B.B.N.; Latawiec, A.E.; Barioni, L.G.; Nobre, C.A.; da Silva Vanderley, P.; Valentim, J.F.; Vianna, M.; Assad, E.D. When enough should be enough: Improving the use of current agricultural lands could meet production demands and spare natural habitats in Brazil. Glob. Environ. Chang. 2014, 28, 84-97. [CrossRef]

16. Instituto Brasileira de Geografia e Estatística (IBGE). National Household Sample Survey-PNAD. Available online: https://www.ibge.gov.br/en/statistics/social/justice-and-security/20293-supplements-pnad4.html? $=\& \mathrm{t}=\mathrm{O}-$ que-e (accessed on 16 August 2020).

17. Szatanowska, A.; Kotlewska, K.; Licznerska, M.; Samociuk, K.; Trackingowe Badanie świadomości i zachowań ekologicznych mieszkańców Polski (Research Report. Tracking Study of Ecological Awareness and Behavior of Polish Citizens). 2018. Available online: https://www.gov.pl/attachment/a93a177c-6eb54631-98a5-335b746c12f0 (accessed on 20 August 2020).

18. Kuchlar, M.; Bridge, G. Down the black hole: Sustaining national socio-technical imaginaries of coal in Poland. Energy Res. Soc. Sci. 2018, 41, 136-147. [CrossRef]

19. Frankowski, J. Attention: Smog alert! Citizen engagement for clean air and its consequences for fuel poverty in Poland. Energy Build. 2020, 207, 109525. [CrossRef]

20. Burchard-Dziubińska, M. Air Pollution and Health in Poland: Anti-Smog Movement in the Most Polluted Polish Cities. Econ. Environ. 2019, 2, 76-90. [CrossRef]

21. Mikusiński, G.; Bubnicki, J.W.; Churski, M.; Czeszczewik, D.; Walankiewicz, W.; Kuijper, D.P. Is the impact of loggings in the last primeval lowland forest in Europe underestimated? The conservation issues of Białowieża Forest. Biol. Conserv. 2018, 227, 266-274. [CrossRef]

22. Kuboń, M.; Latawiec, A.E.; Scarano, F.R.; Drosik, A.; Strassburg, B.B.N.; Grzebieniowski, W.; Bastos, J.G. Searching for solutions to the conflict over Europe's oldest forest. Conserv. Biol. 2018, 33, 476-479. [CrossRef]

23. Niedziałkowski, K.; Blicharska, M.; Mikusiński, G.; Jędrzejewska, B. Why is it difficult to enlarge a protected area? Ecosystem services perspective on the conflict around the extension of the Białowieża National Park in Poland. Land Use Policy 2014, 38, 314-329. [CrossRef]

24. R Core Team. R: A Language and Environment for Statistical Computing; R Foundation for Statistical Computing: Vienna, Austria, 2017. Available online: https://www.R-project.org/ (accessed on 5 October 2020).

25. Holmes, G.; Sandbrook, C.; Fisher, J.A. Understanding conservationists' perspectives on the new-conservation debate. Conserv. Biol. 2017, 31, 353-363.

26. Sandbrook, C.; Fisher, J.A.; Holmes, G.; Luque-Lora, R.; Keane, A. The global conservation movement is diverse but not divided. Nat. Sustain. 2019, 2, 316-323. [CrossRef]

27. Silva, E.A.; Guterman, R. "Há Males Que Vêm Para o Bem." Viomundo 2014. Available online: http://www.viomundo.com.br/voceescreve/edson-aparecido-e-ricardo-guterman-ha-males-que-vempara-o-bem.html (accessed on 16 August 2020). 
28. Nobre, C.N.; Marengo, J.A.; Seluchi, M.E.; Cuartas, L.A.; Alves, L.M. Some characteristics and impacts of the drought and water crisis in southeastern Brazil during 2014 and 2015. J. Water Resour. Prot. 2016, 8, $252-262$. [CrossRef]

29. Marengo, J.A.; Alves, L.M. Crise Hídrica em São Paulo em 2014: Seca e Desmatamento [Water Crisis in Sao Paulo in 2014: Drought and Deforestation]. GEOUSP 2015, 19, 485-494. Available online: http: //dx.doi.\%20org/10.11606/issn.2179-0892.geousp.2015.100879 (accessed on 9 October 2020).

30. Lopes, N.P.; de Freitas, R.P.; Rocha Filho, R.C. How Many More Brumadinhos and Marianas Will We be Faced with Yet? J. Braz. Chem. Soc. 2019, 30, 681-682. [CrossRef]

31. SOS Mata Atlântica. Observando os Rios 2019: O Retrato da Qualidade da Água nas Bacias da Mata Atlântica. Available online: https://www.sosma.org.br/sobre/relatorios-e-balancos/ (accessed on 16 August 2020).

32. Latawiec, A.E.; Strassburg, B.B.N.; Silva, D.; Alves-Pinto, H.N.; Feltran-Barbieri, R.; Castro, A.; Iribarrem, A.; Rangel, M.C.; Kalif, K.A.B.; Gardner, T.; et al. Improving land management in Brazil: A perspective from producers. Agric. Ecosyst. Environ. 2017, 240, 276-286. [CrossRef]

33. Sistema Nacional de Informações sobre Saneamento-SNIS 2019. 24 Diagnóstico dos Serviços de Água e Esgoto; Secretaria Nacional de Saneamento/Ministério do Desenvolvimento Regional: Brasília, Brazil, 2019; 186p. Available online: http://www.snis.gov.br/diagnostico-anual-agua-e-esgotos/diagnostico-dos-servicos-deagua-e-esgotos-2018 (accessed on 16 August 2020).

34. Fundação Nacional de Saúde-FUNASA. Saneamento em Áreas Indígenas do Brasil: Histórico de Atuação da Funasa e Perspectivas; Ministério da Saúde: Brasília, Brazil, 2009. Available online: http://www.funasa.gov.br/documents/20182/38564/Saneamento+em+\%C3\%A1reas+\%C3\%ADndigenas+ do+Brasil.+Hist $\%$ C3\%B3rico+da+atua $\%$ C3\%A7\%C3\%A3o+da+Funasa+e+perspectivas+2009.pdf/ 4c251df2-fad6-4dc1-9497-09c2a8108c07 (accessed on 16 August 2020).

35. Associação Brasileira de Engenharia Sanitária e Ambiental (ABES). Suplemento Saneamento e Convid-19 $1^{\circ}$ Trimestre/2020. Available online: http://abes-dn.org.br/wp-content/uploads/2020/06/ABES_Suplementosaneamento-e-covid-19.pdf (accessed on 16 August 2020).

36. Central Statistical Office (CSO). Concise Statistical Yearbook of Poland; Statistical Publishing Establishment: Warsaw, Poland, 2013. (In Polish)

37. Czerwińska, J.; Wielgosiński, G.; Szymańska, O. Is the Polish Smog a New Type of Smog? Ecol. Chem. Eng. S 2019, 26, 465-474. [CrossRef]

38. Bridges, E.M.; van Baren, J.H.V. Soil: An overlooked undervalued and vital part of the human environment. Environmentalist 1997, 17, 15-20. [CrossRef]

39. Aparin, B.; Suhacheva, E. Methodology of uninterrupted ecological education and soil science. In World Congress of Soil Science; Abstracts; IUSS: Bangkok, Thailand, 2002; p. 1685.

40. Muggler, C.C.; Sobrinho, F.A.P.; Machado, V.A. Educação em solos: Princípios, teoria e métodos. Revis. Bras. Ciênc. Solo 2006, 30, 733-740. [CrossRef]

41. Latawiec, A.E.; Reid, B.; Rodrigues, A.F.; Pena, I.A.B.; Gomes, F.; Pacheco, V.; Strassburg, B.B.N. More effort needed to implement and disseminate soil protection measures for tropical soils. Environ. Res. Lett. 2009, 4, 034009.

42. Mendes, M.S.; Latawiec, A.E.; Sansevero, J.B.B.; Crouzeilles, R.; Moraes, L.F.D.; Castro, A.; Alves-Pinto, H.N.; Brancalion, P.H.S.; Rodrigues, R.R.; Chazdon, R.L.; et al. Look down-There is a gap-The need to include soil data in Atlantic Forest restoration. Restor. Ecol. 2018, 27, 361-370. [CrossRef]

Publisher's Note: MDPI stays neutral with regard to jurisdictional claims in published maps and institutional affiliations.

(C) 2020 by the authors. Licensee MDPI, Basel, Switzerland. This article is an open access article distributed under the terms and conditions of the Creative Commons Attribution (CC BY) license (http://creativecommons.org/licenses/by/4.0/). 